\title{
Financing higher education: experience of Russia and Germany
}

\author{
Y.V.Pereverzeva \\ Institute of Law \\ FSAEI HI "Volgograd State University" \\ Volgograd, Russia \\ pereverzeva@volsu.ru
}

\author{
A. N.Shamne \\ Institute of Law \\ FSAEI HI "Volgograd State University" \\ Volgograd, Russia \\ antonsh97@gmail.ru
}

\begin{abstract}
The article considers the actual problem of financing higher education in a comparative aspect on the example of Russia and Germany. The levels of funding higher education in Russia and Germany are characterised; the main and additional sources of funding are described; the differences in attracting extrabudgetary funds for the development of universities in Russia and Germany are also stated. There are the tendencies, revealed in the designated sphere in the modern period beginning from 2000 to the present moment, and the statistical data provided. The authors describe the criteria that affect the amount and funding streams; highlight problems in applying these criteria, justify the necessity of improving the system of indicators that determine government funding of universities; establish the regularities of financing higher education in such aspects as amounts, supplementary sources, the university status and others; describe the differences in financing universities caused by the system of classifying universities according to their status (budgetary, autonomous, federal, elite et al.) adopted in Russia and Germany; determine the similarities and differences in the financing process in Russia and Germany. In conclusion, they suggest possible directions for improving the system of financing Russian universities taking into account international experience.
\end{abstract}

Keywords - financing, higher education, funding criteria, funding sources

\section{INTRODUCTION}

The problem of attracting finance and financing in any sphere of human activity is always relevant, since this directly affects the development of the corresponding sphere, the efficiency of the activity itself and the competitiveness of the activity results in the market.

At the current stage of the society development, when the economy is undergoing constant changes, one of the most urgent problems in the financial law is the study of legal mechanisms and peculiarities of the financing process in various areas of human activities. One of the areas that attracts scientists' attention is education. Of special interest is the problem of financing higher education. The authors consider sources and mechanisms of the financing process in this area and suggest measures to improve this process $[1,2,3]$.

However, despite such interest to the problem under consideration, there are still many questions especially since it is a question of such "flexible" sphere of activity as education which is characterized by permanent processes of changing, conditioned by the need of integration into the international educational space.

The authors consider it appropriate to compare the problem of financing higher education in Russia with a similar process in Germany since there is a lot of experience in consolidated financing and financing sources diversification in education and science.

\section{METHODS AND RESEARCH}

The regulatory and legal framework governing the process of financing in the sphere of Russian education includes a whole package of documents including Presidential Decrees, Government Decrees and Orders of the Ministry of Education and Science.

Financing higher educational institutions (HEIs) in Russia is carried out at three levels: federal, regional and municipal. However, in fact, the main and significant financial burden is borne by the state. The sources of financing are divided into planned (main) and supplementary. The main sources of funding universities are federal budget funds (the Russian Federation Budget Code, article 21) [4, 5, 6].

Let us consider the trends in financing HEIs in recent years (since 2000 till now). According to official data, which were published in the series of statistical compendiums prepared by the Higher School of Economics, public expenditures on education (consolidated budget) under the article "Higher and Postgraduate Professional Education" amount (in billion rubles) to: 24.4 (in 2000), 125.9 (in 2005), 377.8 (in 2010), 416.8 (in 2011), 464.0 (in 2012), 512.5 (in 2013), 519.7 (in 2014) [7]. In 2016, expenditures amounted to 514.6 billion rubles. [8].

In this case, the following patterns can be observed. From 2000 to 2010 , there is a tendency to increase funding for higher education, and from 2005 to 2010, the amount is twice as much as compared to the previous five-year period. Starting from 2012, this trend is gradually slowing down: in 2012 financing has been increased by 47.2 billion rubles. To compare it with the previous year, next year, the increase covers almost the same amount (48.5 billion rubles.). Since 2014, there has been a reversal trend as the growth in financing has been declining: in 2014 financing increases only 
by 7.2 billion rubles in comparison with 2013; in 2016 - by 5.06 billion rubles in comparison with 2014. The revealed regularities are largely due to the corresponding level of economic development and the current political situation.

As for the structure of expenditures for 2017, the whole education sector occupies only $3.5 \%$; the government plans to reduce the amount of budget-funded places at universities by more than $40 \%$ and the amount of financing the programme for the educational development by more than $20 \%$ [9].

The allocation of funds directly to HEIs depends on the results of their activity. Currently, there are functions of a system for monitoring the effectiveness of higher educational institutions. The basis for monitoring the education system is the Federal Law No. 273-FZ "On Education in the Russian Federation" (Part 5 of Article 97) dated December 29, 2012, and the Rules for Monitoring the Education System, No. 662, approved by the Government of the Russian Federation on August 5, 2013 [10, 11]. In addition, the regulatory and legal framework is constituted with the Decree of the President of the Russian Federation, No. 599, "On measures to implement state policy in the field of education and science" dated May 07, 2012; the Order of the Ministry of Education and Science of Russia, No. 244, "On monitoring the effectiveness of higher educational institutions" dated March 18, 2016 [12-15].

The system of results consists of a number of indicators, the performance of which directly impacts the amount of allocated funds. The main indicators are: educational activity (in particular, monitoring the average USE score of enrolled applicants); the ratio of the number of students and faculty (teaching staff); research activity (grants, projects, etc.); international activity (including the number of foreign students); financial and economic activity; the salary of the faculty as percent of the average wage in the region; employment of graduates and other indicators [16].

Of course, the focus of financing on the result is a big advantage as it stimulates higher education institutions to constantly improve the system of educational and scientific activity. However, in the authors' opinion, some indicators have not been fully developed. In particular, when implementing them, it is necessary to take into account the specifics of a certain fields of study as well as the individual characteristics of the university which include, in particular, the geographical location. Thus, the indicator "the ratio of the number of students and teaching staff" suggests that small groups of students can not be created (for example, less than 15 people). However, such fields of study as, for example, linguistics require learning in small groups because in this case it implies learning a foreign language.

It is very difficult for a number of universities to implement such indicator as international activity because this largely depends on the so-called "provinciality" of the university, its regional location. Many universities can not just attract a large number of foreign students, for example, there are quite a lot of Chinese students primarily in the northeastern part of Russia in contrast to the south, which is understandable because this part is closer to their homeland. As a result, the university is forced to accept all foreigners, even with a weak knowledge of the Russian language.
Another important indicator of the above mentioned ones needs clarification: the demand for graduates in the labor market. In this case, we think that when monitoring the employment of graduates there should be taken into account the priority and the importance of the received qualifications for the economy in general and in the region, in particular. So, if we are talking about technical specialists, medicine, innovations and etc., then, of course, the graduate should work primarily in the specialty. However, in relation to general humanitarian fields of study this indicator should take into account not only the work in the specialty, but the actual successful employment which also allows the graduate to adequately realize his/her humanitarian education in another correlated field (there exist examples when philologists successfully employ themselves in the fields connected with various types of communication like administrators, speechwriters, etc.).

Thus, the system of criteria and indicators that determine the budgetary financing of HEIs requires further improvement. It is also necessary to develop a normative legal act regulating a certain reduction or increase in financing depending on the implementation of established criteria. Today this task is solved by the special commission after summarizing the monitoring results.

Let us consider supplementary sources of financing. In the Russian education system the problem of finding supplementary sources is quite acute, since here we are talking primarily about the extra-budgetary university resources, most of which are formed by the income from learners studying under the agreement on full compensation for the university costs associated with training. Consequently, the fund amount directly depends on the number of such "paying" students. Other ways of finding supplementary financing sources come from the realization of the results of intellectual activity in the service market (for example, through scientific and educational centers), the organization of various courses and programmes (professional development for specialists, financial literacy for the population, etc.), and raising money from various funds. For example, Volgograd State University possesses an endowment fund which is formed at the expense of graduates' donations and is used to support the educational activities of students, researches, etc. [17].

Let us elaborate on the specifics of financing the higher education system in Germany. Here, as in Russia, financing is carried out at three levels: federal (state), regional (land) and local (municipalities). However, the distribution of funds is different: the main financial burden is borne by the land (regional level), it is quite understandable from the very federal system of Germany where the lands possess great financial and economic independence and become the founders of universities. According to the data of the Higher School of Economics, federal expenditures on higher education in Germany make up 3.0\% of total expenditures, in Russia - 1.9\% (according to data in 2014) [7].

Financing sources, like in Russia, are divided into main and supplementary. However, the maximum number and the structure of these sources are different. Thus, the main sources account for approximately $60 \%$ of the total system of 
financing HEIs; by the way, $90 \%$ of them come from the state budget and $10 \%$ from private sector. At the same time, the state sources include the financial funds of the land (80\%) and the federal government (10\%). Supplementary sources account for approximately $40 \%$ of the total system of financing universities; they include grants, private funds, a variety of funds supporting scientific and innovative activities, contracts with enterprises and companies [18].

According to official data, Germany witnesses a tendency to a constant increase of funding for higher education, especially for the period from 2000 to 2013 (sums are given in billions of Euros): in 2000 - 1.9 (from federal government), 15.3 (land); in 2005 - 1.8 and 16.6; in $2010-3.2$ and 19.3; in $2012-4.0$ and 20.7; in $2013-4.9$ and 21.8. Starting in 2014, the increase in funding continues to grow, but at a slower pace; at the same time, redistribution of the load is noticed funding is growing at the expense of the land, but not the government: in 2014 - 5.0 and 23.0 billion Euros; in 2015 - 5.0 and 24 billion Euros [19].

Among the supplementary sources, there are no extrabudgetary funds received from teaching students on a fee basis. However, recently, in the framework of monitoring the quality of education in separate lands, fee-paying education has been introduced for those students who do not meet the deadlines and study more than 12 semesters, for example, see the Higher Education Law of Lower Saxony [20].

Supplementary income sources also include revenues from commercial activities which mainly cover the funds received from the university clinics activities.

It should be noted that in the framework of redistribution of the received budget funds, German universities have greater independence than universities in Russia. In Russia, the division of higher education institutions into budgetary and autonomous ones has expanded the possibilities of the latter in the field of allocating mainly extra-budgetary funds.

Thus, the system of supplementary sources of funding for universities in Germany is more orderly and stable, because, unlike in Russia, it operates for a long time and operates by an established scheme. Supplementary funding sources in Germany are of interest not only for the universities themselves, but for the federal government and the lands. So, they jointly developed programmes aimed at allocating supplementary funds to the universities on a competitive basis - a Package of pacts [21].

In Germany, the criteria and indicators, influencing the process of financing HEIs, are singled out within the framework of both core and supplementary funding. Important indicators include: the number of graduates and the duration of their study; additional attraction of funds from private sector for holding researches; the number of defended theses; the number of students getting applied bachelor's degree; the number of scientific personnel positions, etc. [18]. As it can be seen from this list, a somewhat different approach is presented in this case, as students' graduation and the scientific potential are primarily important.

Speaking about financing of any activity, it should be noted that the result will be most important here. The authors believe that the result should be viewed not only from the perspective of the achieved, but also of coming achievements. In the Russian system of financing higher education, as it has been determined by the analysis, the obtained result is primarily important. In Germany, the emphasis is not so much on the results of educational and scientific activity, but rather on the prospects and the future result. This is largely due to the relatively stable development of the leading sectors of the economy, the possibility to make accurate forecasts of the demand for certain specialists, studies, etc.

In the framework of the issue of financing higher education, we should focus on the issue of financing HEIs depending on their status. In Russia, the following grading of universities is currently adopted [22]: leading universities which are federal, national research HEIs; an individual place is occupied by the Moscow State University and the St. Petersburg State University; "backbone" or flagship universities that should have an impact on regional economy, national development and serve as models; other universities. Accordingly, the financing of leading, flagship universities, by virtue of their status and assigned tasks, exceeds by far the funding of the rest ones (see, for example, the Government Decree No. 211 "On the allocation of subsidies to leading universities" dated March 16, 2013) [23, 24].

However, there has also been a trend towards a decrease in funding in this area by 2017. In particular, it is planned to reduce funding of the leading universities by 12.7 billion rubles in 2017-2019 [9]. But it was assumed before that 14.5 billion rubles should be allocated to support universities in 2017 and the next three years. Therefore, the Government reduces financing to 10.6 billion rubles in 2017 , to 10.2 billion rubles in 2018 and up to 10.0 billion rubles in 2019. On the other hand, large financial flows are planned for the flagship higher education institutions: allocating subsidies supplementary to the existing state financing in the amount of up to 200 million rubles annually per each unified university within three years (starting from 2015) (Ministry of Education and Science).

This grading of universities in Russia was primarily borrowed from Western practice. In Germany, there has been an initiative to allocate elite universities (Exellenzinitiative) since 2005 , which is being carried out in several stages. This initiative of superiority in state and lands support of science and research in German universities began at the same time with fundamental adjustments to the system of higher education in the framework of the Bologna Process.

Let us view the initiative of superiority developed in Germany in 2004-2005 in more detail. It was planned that this initiative of superiority should consist of three trends:

1. "The concept of the future" (Zukunftskonzepte). The concept of the future involves the elaboration of the concept of the future universities development in the field of scientific research in certain areas, the definition of objectives and tasks, ways to solve the established problems, that is, strategic development. Initially, this project was presupposed to create one cluster of superiority and one school of doctoral students. 
At present, individual universities have been singled out within the framework of this concept in Germany and are now called "elite universities".

2. "The cluster of superiority" (Exzellenzcluster) includes support for research in a single area. Scientific research being undertaken on a single but rather broad topic is primarily important. The idea is not to explore a selected area, but to engage, for example, 25 renowned scientists to cooperate on a significant scientific or economic issue. This should also lead to a change in the organizational structure of the university

3. Students School "Graduiertenschule" provides support for students in a wide range of scientific branches. It should be emphasized that the scientific research must be conducted primarily by the doctoral students themselves, rather than by their scientific advisers. Every such school must receive solid financial support [25].

Since 2017 this support programme was named as a strategy of superiority. This new strategy now supports two areas: clusters of superiority and universities of superiority.

While being realized the certain corrections were made to the initiative. On the first step (till 2012), Germany distinguished 50 universities of this type and elite clusters on a competitive basis; on the second step (till 2017), the financing increased up to 2.7 billion Euro and there were distinguished 45 universities and 43 clusters (till 2017) (go to the official website of Federal ministry of education and scientific research BMBF) [25]. Unlike Russia, financing such types of higher educational institutions in Germany increases correspondingly on each step.

According to researchers' investigations, on the one hand, such practice of defining the leading higher educational institutions is quite effective for developing science, innovations, competitiveness, improving the quality of education provided [2, 26, 27]. But on the other hand, the institutions out of this list faced some difficulties and especially financial. As it has been already mentioned, Germany has been attracting extrabudgetary funds and it has became a wide-spread practice, but in Russia it has still been a great problem. Therefore, despite certain advantages this course on distinguishing the leading, elite institutions for financing should also take into account the interests of other institutions which are out of this list.

The advantages of the German course concern in this case the more frequent change of institutions' position within the elite list, the institution acquires the status of the elite one for the certain period (this is agreed upon in advance). Therefore, any institution has an opportunity to take part in further contest and enter the elite list. In comparison with them, Russian institutions acquire the federal status without any time limitation.

Thus, the comparative analysis of financing higher education in Russia and Germany makes it possible to single out the following patterns:

- in Russia there has been a decline in the funding volume for ordinary universities since 2014 and for leading ones since 2017; the priority area for funding is the region's flagship universities. In Germany, on the contrary, there is a tendency to increase the funding for higher education institutions and, especially, elite universities;

- the allocation of funds between higher education institutions in the framework of financing higher education is focused on the achieved results in Russia and on the projected results in Germany;

- the additional sources of funding in the Russian higher education system depend firstly on the number of students studying on a contract basis but in the German education system - on the number of agreements concluded between universities and land administration or enterprises;

- $\quad$ among the leading universities, the advantages in the framework of financing are available for the basic universities of the region in Russia and for elite universities in Germany.

\section{CONCLUSION}

The above mentioned facts allow us to propose the following possible directions for improving the system of financing Russian universities taking into account foreign experience (by the example of Germany):

1. The regulatory framework governing the process of financing higher education should be streamlined, since financing is a determining factor for higher education institutions to perform their activities. Normative acts concerning the financing of universities are not systematized and this study has shown certain difficulty to search them. It is advisable to create an additional rubric on the website of the Ministry of Education and Science in the section "Higher Education" and place there the relevant regulatory and legal acts of different departments and structures.

2. It is necessary to increase the amount of state financing for universities. At the moment, the amount of financing does not correspond to the expenses of high-quality training of future specialists. It is possible to make such increase by concluding agreements (contracts) between the regional authorities and the relevant higher educational institution on training certain specialists, carrying out innovative projects, followed by mandatory participation of graduates in this area for a specific period and subsequent implementation of projects into the region's economy (and this should be not onetime projects, but long-term ones). In this case, this implies extensive application and implementation of employersponsored education (this form of education exists, but is applied quite rare and selectively).

3. The criteria should be clarified and supplemented, including a number of indicators that affect the university financing process (in particular, the number of foreign students, the employment of graduates, etc.). These criteria should include not only the results, but also the prospects, possible outcomes. Actually, the issues of reducing or increasing university funding according to the results of monitoring the effectiveness of university activities should be set out in a separate regulatory legal act. 
4. The distribution of financial flows between the leading universities and the rest ones need a deeper and more reasonable analysis. It is necessary to establish certain terms which presuppose the possibility of altering the status of a leading higher education institution and assigning this status to another institution on a competitive basis. This will promote healthy competition and stimulate educational and scientific activities.

The proposed possible ways of improving the system of financing higher education will improve the finances of higher education institutions to a certain extent and will promote the implementation of the principle of equal rights and opportunities for all state universities.

\section{References}

[1] I.A. Avetisyan, "Problems of financing higher education in modern Russia," "Economic and social changes: facts, trends, forecast," No. 1 (25). Pp. 108-122, 2013.

[2] M.N. Kulakova, "International models of financing universities and their application to higher education in Russia during the reform of the higher education system," "Territory of new opportunities. Bulletin of Vladivostok State University of Economics and Service," No. 1 (10), pp. 51-60, 2011.

[3] M.A. Suzdalova, V.G. Lizunkov, E.Yu. Malushko, N.A. Sytina, V.E. Medvedev, "Innovative Forms of Partnership in Development and Implementation of University-Business Cooperation," "The European Proceedings of Social \& Behavioural Sciences EpSBS”. Vol. XIX. Article \#61. Pp. 450-455, 2017.

[4] V.A. Yurga, "Structure and mechanisms of financing the system of higher professional education as a condition for innovative development of higher education (Russian and foreign experience)," "Siberian Financial School," No. 3, pp. 1-11, 2011.

[5] N. Pomortseva, V. Kurilenko, Yu. Biryukova, V. Sinyachkin, M.Makarova, "Integrative didactic model of linguacultural adaptation of foreign students at an international university," Book 1, vol.1, pp.845853, 2016.

[6] "Budget Code of the Russian Federation" No. 145-FZ dated July 31, 1998 (amended on December 28, 2016). http://www.consultant.ru/document/cons_doc_LAW_19702/

[7] L.M. Gokhberg, I.Yu. Zabaturin, G.G. Kovaleva and others, "A brief statistical compilation "Education in Figures": 2014; 2016". Nat. Issled. University Higher School of Economics. Moscow: NIU HSE. 2014, 2016. 80 p.

[8] "Expenses of the consolidated budget of the Russian Federation in the Education section in 2016, billion rubles". http://fin.edu.ru/InfoPanel/min_obr1.html\#page0_target.

[9] "Decree of the Government of the Russian Federation No. 171 dated February, 102017 "On Amending Resolution of the Government of the Russian Federation No. 211 dated March 16, 2013"'”. http: //publication.pravo.gov.ru/Document/View/0001201702140009?Index= $0 \&$ rangeSize $=1$.

[10] "Federal Law No. 273-FZ dated December 29, 2012 "On Education in the Russian http://www.consultant.ru/document/cons doc LAW_140174.
[11] "Rules for monitoring the education system approved by the Government of the Russian Federation No. 662 dated August 5, 2013”, http://www.garant.ru/products/ipo/prime/doc/70329494.

[12] "Decree of the President of the Russian Federation No. 599 dated May, 072012 "On measures to implement state policy in the field of education and science". https://rg.ru/2012/05/09/nauka-dok.html

[13] "Order of the Ministry of Education and Science of Russia No. 244 dated March 18, 2016 "On monitoring the effectiveness of educational institutions of higher education"', http://минобрнауки.рф/документы/8060

[14] E. Malushko, O. Maletina, V. Lizunkov, V. Tsybaneva, "Use of virtual learning system for educating students with disabilities and special needs," "3nd international multidisciplinary scientific conference on social sciences \& arts SGEM 2016: conference proceedings," Book 1, vol. 1. pp. 481-487, 2016.

[15] M. Loschilova, V. Lizunkov, A. Zavyalova, "Professional Training of Bachelors in Mechanical Engineering, Based on Networking Resources," "Procedia Social and Behavioral Sciences," vol. 206, pp. 399-405, 2015.

[16] "Methodology for calculating indicators to monitore the effectiveness of higher educational institutions in 2016 (based on data from Form No. 1Monitoring for 2015) (approved by the order of the Ministry of Education and Science of the Russian Federation No. AK-6/05vn dated March 21, 2016)". http://www.garant.ru/products/ipo/prime/doc/71273326.

[17] "Endowment fund". http://www.volsu.ru/fck.

[18] "Bildungsxperten". http://www.bildungsxperten.net/wissen/wie-werdenhochschulen-finanziert.

[19] M.A. Suzdalova, V.G. Lizunkov, E.Yu. Malushko, N.A. Sytina, V.E. M edvedev, "Innovative Forms of Partnership in Development and Implementation of University-Business Cooperation," "The European Proceedings of Social \& Behavioural Sciences EpSBS," vol. XIX. Article \#61. Pp. 450-455, 2017.

[20] "Niedersächsisches Hochschulgesetz (NHG)". Dritter Abschnitt. §11. http://www.schure.de/22210/nhg.htm\#p13.

[21] "Hochschulpakt 2020". https://www.bmbf.de/de/hochschulpakt-2020506.html.

[22] "Federal Law "On Amendments to Certain Legislative Acts of the Russian Federation on the Activity of Federal Universities" No. 18-FZ dated February, $10 \quad 2009$ ". http://www.consultant.ru/document/cons_doc_LAW_84791.

[23] "Decree of the Government of the Russian Federation No. 211 dated March 16, 2013 "On measures of state support for leading universities of the Russian Federation with a view to enhancing their competitiveness among the world's leading scientific and educational centers"'. http://government.ru/docs/9988.

[24] M.A. Suzdalova, V.G. Lizunkov, E.Yu. Malushko, N.A. Sytina, V.E. M edvedev, "Innovative Forms of Partnership in Development and Implementation of University-Business Cooperation," "The European Proceedings of Social \& Behavioural Sciences EpSBS". Vol. XIX, Article \#61, pp. 450-455, 2017.

[25] “BMBF". https://www.bmbf.de/de/die-exzellenzstrategie-3021.html

[26] M. Hartmann, "Die Exzellenzinitiative - ein Paradigmenwechsel in der deutschen Hochschulpolitik," "Leviathan," No. 4, pp. 447-465, 2006.

[27] V.G. Lizunkov, M.G. Minin, E.Y. Malushko, V.E. Medvedev, "Developing economic and managerial competencies of bachelors in mechanical engineering," "SHS Web of Conferences", vol. 28, Article \#01063, 2016. 